\title{
PERAN GURU SEJARAH ABAD 21 DALAM MENGHADAPI TANTANGAN ARUS GLOBALISASI
}

\author{
Agus Susilo dan Sarkowi \\ Program Studi Pendidikan Sejarah, STKIP PGRI Lubuklinggau \\ agussusilo594@yahoo.co.id dan sarkowisulaiman@gmail.com
}

\begin{abstract}
Teachers are major factor in education and professional teachers are those who inspire and give high motivation to ther students. More specific, teachers, including history teacher, also ought to look inside their students'characters and appreciate their backgrounds. The forming of students' mental and characters are not detached from transfer of values issues. In the 21st century where everything is affected by globalization, teachers should keep committed to educate and cultivate values of national characters. Learning inovation is truly necessary in education, therefore positive impacts of globalization must be utilized.

Abstrak: $\quad$ Guru merupakan faktor utama dalam pendidikan dan guru profesional adalah sosok yang dapat menjadi sumber inspirasi dan pematik gairah belajar bagi anak didiknya. Lebih spesifik lagi, guru, termasuk juga guru sejarah, harus mampu melihat karakter anak didiknya dan menghargai setiap perbedaan yang menjadi latar belakang siswanya. Pembentukan mental dan karakter siswa tidak akan lepas dari persoalan penanaman nilai-nilai. Di abad ke-21 di mana semua yang terjadi terpengaruh oleh globalisasi, yang juga menghampiri dunia pendidikan, guru sepatutnya terus berjuang untuk tetap berkomitmen mendidik dan menanamkan nilai karakter bangsa. Inovasi pembelajaran sangat diperlukan dalam dunia pendidikan, maka dari itu dampak positif globalisasi harus dapat dimanfaatkan.
\end{abstract}

Kata Kunci: $\quad$ guru sejarah, globalisasi

\section{PENDAHULUAN}

Pendidikan adalah investasi sumber daya manusia (SDM) jangka panjang yang mempunyai nilai strategis bagi kelangsungan peradaban manusia di dunia. Salah satu komponen penting dalam pendidikan adalah guru. Guru dalam konteks pendidikan mempunyai peranan yang besar dan strategis. Hal ini disebabkan karena guru yang berada dibarisan terdepan dalam pelaksanaan pendidikan. Guru yang berlangsung berhadapan dengan peserta didik untuk mentransfer ilmu pengetahuan dan teknologi, sekaligus mendidik dengan nilai-nilai positif melalui bimbingan dan keteladanan. Kebutuhan guru yang berkualitas semakin tinggi saat ini harus disikapi secara positif oleh para pengelola pendidikan guru. Respons positif ini harus ditunjukkan dengan senantiasa meningkatkan mutu program pendidikan yang ditawarkannya. Perbaikan mutu pendidikan pada jenjang pendidikan tinggi ini jelas akan membawa dampak positif bagi penciptaan guru yang berkualitas kelak dikemudian hari (Oviyanti, 2013, hlm. 268).

Ketika ilmu pengetahuan masih terbatas, ketika penemuan hasil-hasil teknologi belum berkembang hebat, seperti sekarang ini, maka peran utama guru di Sekolah adalah menyampaikan ilmu pengetahuan sebagai warisan kebudayaan masa lalu yang dianggap berguna sehingga harus dilestarikan. Peran guru sebagai sumber belajar sangat erat dengan penguasaan materi pelajaran. Guru yang baik manakalah ia dapat menguasai materi pelajaran dengan baik, sehingga benar-benar ia berperan sebagai sumber belajar bagi anak didiknya. Guru adalah komponen yang sangat menentukan dalam implementasi suatu strategi pembelajaran.
Keberhasilan suatu implementasi strategi pembelajaran akan tergantung pada kepiawaian guru dalam menggunakan metode, teknik dan taktik pembelajaran (Sanjaya, 2016, hlm. $52)$.

Dalam situasi masyarakat yang selalu berubah, idealnya pendidikan tidak hanya berorientasi pada masa lalu dan masa kini, tetapi sudah seharusnya merupakan proses yang mengantisipasi dan membicarakan masa depan. Pendidikan seharusnya melihat jauh ke depan dan memikirkan apa yang akan dihadapi peserta didik di masa yang akan datang. Apabila kita ingin meningkatkan prestasi, tentunya tidak akan terlepas dari upaya peningkatan kualitas pembelajaran di Sekolah. Misalnya dengan adanya penataran guru, penyediaan buku paket, dan alat-alat laboratorium serta penyempurnaan kurikulum. Berdasarkan hasil evaluasi upaya-upaya tersebut ternyata belum berhasil meningkatkan prestasi peserta didik secara optimal sebagaimana yang diinginkan. Salah satu perubahan paradigma pembelajaran tersebut adalah orientasi pembelajaran yang semula berpusat pada guru (teacher centered) berubah menjadi berpusat pada murid (student centered), metodologi yang semula lebih didominasi ekspositori berganti ke partisipatori, dan pendekatan yang semula lebih banyak bersifat tekstual berubah menjadi konstektual. Satu inovasi yang menarik mengiring perubahan paradigma tersebut adalah ditemukan dan ditetapkannya model-model Pembelajaran Inovatif dan Konstruktif atau lebih tepat dalam mengembangkan dan menggali pengetahuan peserta didik secara konkrit dan mandiri (Triyanto, 2007, hlm. 2-3).

Guru saat ini menghadapi tantangan yang jauh lebih besar dari era sebelumnya. Guru menghadapi klien yang 
jauh lebih beragam, mata pelajaran yang lebih kompleks dan sulit, standard proses pembelajaran dan juga tuntutan capaian kemampuan berpikir siswa yang lebih tinggi. Hal ini disebabkan transformasi besar pada aspek sosial, ekonomi, politik, dan budaya yang didorong oleh perkembangan ilmu pengetahuan dan teknologi yang pesat, perubahan demografi, globalisasi dan lingkungan yang berdampak besar pada persekolahan dan profesionalisme guru (Andriani, 2010, hlm. 78-79).

Pada dasarnya, pendidikan berfungsi untuk memenuhi kebutuhan masyarakat. Oleh karena itu, kurikulum harus berdasarkan kebutuhan masyarakat dan diarahkan untuk memenuhi kebutuhan tersebut. Kurikulum yang demikian adalah kurikulum yang relevan dengan masyarakat. Di balik itu, masyarakat merupakan lingkungan pendidikan, dalam artian suatu lingkungan yang mempengaruhi Sekolah dan sebaliknya Sekolah memengaruhi kehidupan masyarakat. Kebutuhan masyarakat mendorong munculnya permintaan yang perlu dipenuhi. Berdasarkan permintaan-permintaan tersebut, maka perencanaan kurikulum dapat memilih bahanbahan dan pengalaman-pengalaman kurikulum yang relevan (Hamalik, 2013, hlm. 79).

Pada dasarnya, sesuatu dapat dikatakan sebagai proses apabila menyangkut keberlangsungan dan kesinambungan sesuatu itu sejak dimulai sampai berakhir. Keberlangsungan dan kesinambungan sesuatu itu berkaitan erat dengan keterbatasan kemampuan manusia yang tidak memungkinkannya mencapai titik kesempurnaan absolut dari hasil karyanya dengan serta merta. Suatu proses biasanya dilalui dengan menentukan tahap-tahap tertentu. Pertahapan dapat didasarkan atas kurun waktu, atas sasaran, atas penggunaan dana atau kriteria lainnya. Setiap tahap diusahakan dan diharapkan berakibat pada peningkatan hasil yang dicapai dengan tingkat kesempurnaan yang lebih tinggi. Dalam administrasi hal ini sangat jelas terlihat bila dikaitkan dengan seluruh administrasi dalam rangka usaha pencapaian tujuan (Siagian, 2012, hlm. 3).

Pendidikan yang profesional akan dapat mengembangkan dan membentuk watak serta peradaban bangsa. Guru adalah bagian dari kesadaran sejarah pendidikan di dunia. Sebagai orang yang digugu dan ditiru seorang guru dengan sendirinya memiliki peran yang luar biasa dominannya bagi peserta didik. Dalam sebuah proses pendidikan guru merupakan satu komponen yang sangat penting, selain komponen lainnya, seperti tujuan, kurikulum, metode, sarana dan prasarana lingkungan dan evaluasi. Seiring dengan laju perkembangan pemikiran manusia yang melahirkan peradaban yang sangat cepat pertumbuhannya ditandai dengan kemajuan teknologi informasi yang kemudian dikenal dengan era global dengan konsekuensi globalisasi. Globalisasi menawarkan paradigma baru dalam pendidikan. Tentunya juga merupakan tantangan baru bagi guru profesional yang semakin hari semakin meningkat (Syukur, 2012, hlm. 11).

Peran pendidikan dalam pembentukan akhlak/karakter/ kepribadian adalah melengkapi peran yang dilakukan oleh pihak keluarga dan masyarakat. Melalui pembelajaran yang lebih berfokus pada tenaga pengajar. Melalui pembelajarann yang berfokus pada peserta didik, akan diperoleh sumber daya insani yang telah berhasil memperoleh pengalaman belajar dalam pencapaian suatu kompetensi. Peserta didik tidak sekedar memperoleh pengetahuan atau keterampilan, melainkan dilibatkan dalam seluruh proses untuk memperoleh pengetahuan atau keterampilan tersebut. Peran pendidikan dalam mempersiapkan sumber daya insani unggul akan benar-benar diuji apakah pendidikan mampu memberikan pengalaman belajar bagi peserta didik atau memilih menggunakan pendekatan pembelajaran yang hanya mampu menyampaikan pengetahuan atau keterampilan yang terkait dengan sebuah kompetensi tanpa mampu memberikan pengalaman belajar nyata kepada para peserta didik (Joyoatmojo, 2011, hlm. 6-10).

Tujuan pembelajaran pada hakikatnya adalah perubahan perilaku siswa, baik perubahan perilaku dalam bidang kognitif, afektif, maupun psikomotorik. Bloom memperkenalkan pengembangan perilaku dalam bidang kognitif, yaitu pengembangan kemampuan intelektual siswa, contohnya kemampuan penambahan wawasan dan informasi agar pengetahuan siswa lebih baik. Peraturan Pemerintah Nomor 19 Tahun 2005 Pasal 20, menyebutkan bahwa perencanaan pembelajaran meliputi silabus dan rencana pelaksanaan pembelajaran yang memuat sekurang-kurangnya tujuan pembelajaran, materi pelajaran, metode pembelajaran, sumber belaja, dan penilaian hasil belajar (Agung \& Wahyuni, 2013, hlm. 5-6).

Mengajar yang berhasil menuntut penggunaan metode yang tepat. Seorang guru tentu mempunyai metode dan seorang guru yang baik akan memahami dengan baik metode yang digunakannya sebab tidak ada satu metode yang baik untuk semua mata pelajaran. Ia harus mengetahui bukan hanya bahan/materi pelajaran akan tetapi juga masalah-masalah siswa, sebab melalui metode mengajar ia harus mampu memberi kemudahan belajar kepada siswa dalam proses belajar. Mengajar dapat membantu siswa memperoleh sejumlah bahan pelajaran tertentu, gagasangagasan, keterampilan atau sikap. Juga diasumsikan oleh guru bahwa siswa dapat mengasimilasikan dengan baik apa yang telah diajarkan kapada siswa. Namun dapat juga guru tidak mengajar tetapi siswa tetap mempelajari sesuatu (Wahab, 2007, hlm. 36-37).

Di abad 21 telah terjadi transformasi besar pada aspek sosial, ekonomi, politik dan budaya yang didorong oleh empat kekuatan besar yang saling terkait, yaitu kemajuan ilmu dan teknologi, perubahan demograsi, globalisasi dan lingkungan. Sebagai contoh, kemajuan teknologi komunikasi dan biaya transportasi yang semakin murah telah memicu globalisasi dan menciptakan ekonomi global, komunitas global, dan juga budaya lokal. Masyarakat industrial berubah menjadi masyarakat pengetahuan. Perubahan lingkungan, misalnya pemanasan global telah berdampak pada kebutuhan peningkatan kesadaran dan tanggung jawab masyarakat terhadap lingkungan. Kekuatan-kekuatan ini juga berdampak pada dunia pendidikan, khususnya persekolahan (Andriani, 2010, hlm. 79). 
Globalisasi sebagai sebuah gejala tersebarnya nilai-nilai dan budaya tertentu ke seluruh dunia, sehingga menjadi budaya dunia (world culture), telah terlihat sejak lama. Cikal bakal dari persebaran budaya dunia ini dapat ditelusuri dari perjalanan para penjelajah Eropa Barat ke berbagai tempat di dunia ini. Namun perkembangan globalisasi kebudayaan secara intensif terjadi pada awal abad ke-20 dengan perkembangannya teknologi komunikasi. Kontak melalui media menggantikan kontak fisik sebagai sarana utama komunikasi antar bangsa. Perubahan tersebut menjadikan komunikasi antar bangsa lebih mudah dilakukan. Hal ini menyebabkan semakin cepatnya perkembangan globalisasi kebudayaan, baik di bidang pakaian, bahasa, perilaku, maupun lainnya (Syukur, 2012, hlm. 18).

Kemajuan teknologi digital berdampak besar terhadap segala bidang, termasuk pendidikan. Pemanfaatan teknologi informasi dan komunikasi (TIK) untuk pendidikan dan pembelajaran mau tidak mau melibatkan disiplin teknologi pendidikan. Teknologi pendidikan menjadi salah satu dari tenaga kependidikan yang hadir untuk mendukung tenaga pendidik. Tentu saja disiplin teknologi pendidikan menyiapkan sumber daya manusia dengan keahlian khusus. Fenomena pemikiran umum yang terdapat di masyarakat dalam konsep teknologi yang dikemukakan para pakar. Teknologi menjadi bukti kecanggihan proses berpikir manusia. Teknologi muncul karena manusia ini berpikir dan kerja keras untuk memfasilitasi kehidupan setiap anggota masyarakat yang menjadi lebih baik. Teknologi juga terkait dengan nilai-nilai keagamaan yang memuja alam semesta sebagai teknologi yang tidak dapat ditandingi oleh siapa pun. Teknologi menjadi bukti kebudayaan dan peradaban manusia yang memiliki pemikiran modern dan bermanfaat bagi sesama (Prawiradilaga, 2012, hlm. 19).

Dalam masyarakat seperti itu, peran pendidikan dan guru sangat penting dan strategis, terutama dalam memberikan bimbingan, dorongan, semangat, fasilitas kepada masyarakat dan peserta didik untuk memperoleh ilmu pengetahuan dan keterampilan menggunakan teknologi. Selain itu, tidak kalah pentingnya adalah peran pendidikan dalam memberikan arahan dan bimbingan agar penguasaan teknologi tidak menjadi bumerang bagi masyarakat, yang disebabkan kurangnya penghayatan terhadap etika. Pendidikan dan guru dapat menumbuhkan pemahaman etika yang benar, agar kehidupan manusia tidak terancam oleh karena kemajuan teknologi itu sendiri. Manakala pendidikan mengisyarakatkan adanya keharusan peserta didik untuk menguasai teknologi, maka tentu tidak kalah pentingnya peran guru itu sendiri untuk lebih dulu menguasai ilmu pengetahuan dan teknologi agar dapat memberikan pengetahuan dan keterampilan teknologi ter-update kepada peserta didiknya (Oviyanti, 2013, hlm. 270).

Sejarah (studi tentang manusia beserta perkembangannya yang mengagumkan melewati abad-abad keberhasilan) dapat dikatakan berasal dari manusia itu sendiri. Pada abad ke19 dan awal abad ke-20, ketika peranan ilmu pengetahuan semakin penting, sejarah mulai dianggap sebagai ilmu yang sesungguhnya tentang masyarakat, dan dengan demikian menjadi ilmu tentang ilmu pengetahuan. Sejarah modern tidak hanya memerhatikan peristiwa-peristiwa politik dalam kehidupan bangsa, tetapi juga memerhatikan aspek ekonomi, sosial, kultural, dan religius dalam perkembangan bangsa. Konsep sejarah dewasa ini memberikan tekanan pada sejarah sebagai evolusi, pertumbuhan, dan perkembangan peradaban manusia dari abad ke abad. Konsep sejarah dewasa ini menekankan pada hubungan dan kesatuan yang positif antara sejarah suatu negara dan sejarah dunia (Kochhar, 2008, hlm. 11-12).

Pemahaman konsep yang baik akan memudahkan kita menyimpulkan karakteristik-karakteristik dari kategori yang lebih besar pada kategori yang lebih kecil. Dalam sejarah terdapat sejumlah konsep seperti revolusi, reformasi, dan demokrasi. Konsep-konsep ini, pembelajar sejarah akan lebih mudah memahami peristiwa-peristiwa yang dipelajarinya. Terakhir, fakta adalah pernyataan mengenai dunia yang akan diamati secara langsung dan biasanya hanya muncul satu kali, baik yang terjadi pada masa lalu maupun sekarang. Pemahaman tentang perkembangan kesadaran sejarah masyarakat Indonesia berimplikasi terhadap metode pembelajaran sejarah yang digunakan. Metodenya disesuaikan dengan jenis sumber sejarah, sebagai media pembelajaran. Lewat metode ini, pembelajar diperkenalkan dengan karyakarya historiografi yang dihasilkan oleh masyarakat lokal, sehingga diperoleh perspektif sejarah masyarakat "dari dalam" dengan pendekatan dan pandangan Indonesiasentris (Hamid, 2014, hlm. 22-23).

\section{METODE PENELITIAN}

Bentuk penelitian ini adalah kualitatif deskriptif yaitu penelitian yang menyajikan temuan dalam bentuk deskriptif kalimat yang rinci, lengkap, dan mendalam yang menggambarkan situasi sebenarnya untuk mendukung penyajian data. Data yang dikumpulkan tersebut berupa katakata, kalimat atau gambar yang memiliki arti lebih bermakna dari pada sekedar sajian angka atau frekuensi (Sutopo, 2006, hlm. 20). Teknik pengumpulan data merupakan langkah yang paling utama dalam penelitian, karena tujuan utama dari penelitian ini adalah mendapatkan data. Tanpa mengetahui teknik pengumpulan data, maka peneliti tidak akan mendapatka data yang memenuhi standar data yang ditetapkan (Sugiyono, 2013, hlm. 308).

Studi kepustakaan merupakan sebuah tindakan peneliti dalam mencari informasi yang diperlukan dari buku referensi baik dari buku bersifat teks maupun sumber pustaka lainnya melalui perpustakaan dan data internet. Teknik pengumpulan data yang juga berperan besar dalam penelitian kualitatif adalah dokumentasi. Teknik dokumentasi ini dapat membuat peneliti memperoleh informasi dari bermacam-macam sumber tertulis atau dari dokumen yang ada pada informan dalam bentuk peninggalan budaya, karya seni dan karya fikir. Studi dokumentasi yaitu mengumpulkan dokumen dan data-data yang diperlukan dalam permasalahan penelitian lalu ditelaah secara intens sehingga dapat mendukung dan menambah kepercayaan dan pembuktian suatu kejadian (Satori \& Komariah, 2010, hlm. 1146-149). 


\section{PEMBAHASAN}

\section{Permasalahan Pendidikan Abad 21 di Indonesia}

Pada saat bangsa Indonesia menghadapi permasalahan kompleks yang disebabkan oleh berbagai krisis yang melanda, maka tantangan dalam menghadapi era globalisasi yang bercirikan keterbukaan dan persaingan bebas semakin mendesak. Dalam waktu yang mendesak Indonesia harus mampu mempersiapkan sumber daya manusia yang profesional, tangguh, dan siap pakai. Untuk mendukung itu, maka kualitas pendidikan nasional perlu segara ditingkatkan, sehingga tujuan pendidikan nasional secara keseluruhan dapat tercapai. Reformasi pendidikan dengan berbagai segmen-segmennya merupakan suatu kebutuhan dan juga suatu imperative action. Masalah serius yang dihadapi bangsa Indonesia setelah proklamasi kemerdekaan, adalah masalah pembangunan dan pembinaan bangsa (nation and character building). Dalam upaya membentuk dan menjaga keberagaman dalam keserasian itu diperlukan berbagai upaya yang dapat membina sikap-sikap positif yang saling menghormati, menghargai, mengakui eksistensi, dan kerja sama di antara berbagai keanekaragaman tersebut (Aman, 2011, hlm. 2).

Sejarah perlu diajarkan untuk memperlihatkan kepada anak tentang konsep waktu, ruang, dan masyarakat, serta kaitan antara masa sekarang dan masa lampau, antara wilayah lokal dan wilayah lain yang jauh letaknya, antara kehidupan perorangan dan kehidupan nasional, dan kehidupan dan kebudayaan masyarakat lain dimana pun dalam ruang dan waktu. Untuk memperoleh pemahaman yang tepat tentang peristiwa yang sedang berlangsung, diperlukan pemahaman tentang berbagai peristiwa pada masa lampau yang menghasilkan kondisi sekarang ini. Bahasa, tradisi, dan berbagai kebiasaan yang saat ini ada hanya dapat dipahami melalui studi tentang pertumbuhan dan perkembangannya dalam ruang dan waktu. Konsep tentang waktu, ruang dan masyarakat sangat penting dalam kaitannya dengan masa sekarang ini (Kochhar, 2008, hlm. 30-31).

Ketika ilmu pengetahuan masih terbatas, ketika penemuan hasil-hasil teknologi belum berkembang hebat, seperti sekarang ini, maka peran utama guru di Sekolah adalah adalah menyampaikan ilmu pengetahuan sebagai warisan kebudayaan masa lalu yang dianggap berguna sehingga harus dilestarikan. Peran guru sebagai sumber belajar berkaitan erat dengan penguasaan materi pelajaran. Melalui usaha yang sungguh-sungguh, guru ingin agar ia mudah menyajikan bahan pelajaran dengan baik. Guru perlu memahami berbagai jenis media dan sumber belajar beserta fungsi masing-masing media tersebut. Pemahaman akan fungsi media sangat diperlukan, belum tentu suatu media cocok digunakan untuk mengerjakan semua bahan pelajaran (Sanjaya, 2016, hlm. 23). Mutu pendidikan dengan sendirinya akan tercermin dari mutu sumber daya manusia, di mana sumber daya manusia kita pada umumnya masih rendah, berarti mutu pendidikan pun secara mayoritas masih rendah. Guru beranggapan tugasnya hanya mentransfer pengetahuan yang dimiliki guru kepada siswa dengan target tersampaikannya topik- topik yang tertulis dalam dokumen kurikulum kepada siswa. Pada umumnya guru tidak tertulis memberi inspirasi kepada siswa untuk berkreasi dan tidak melatih siswa untuk hidup mandiri. Pelajaran yang disajikan guru kurang menantang siswa untuk berpisah. Akibatnya siswa tidak menyenangi pelajaran. Secara internasional, mutu pendidikan di Indonesia masih rendah menjawab soal-soal hafalan, tetapi tidak dapat menjawab soal-soal yang memerlukan nalar atau keterampilan proses. Paradigma yang hanya mementingkan hasil tes harus segera diubah menjadi memperhatikan proses pembelajaran, sementara hasil tes merupakan dampak dari proses pembelajaran yang benar (Daryanto \& Rahardjo, 2012, hlm. 37-38).

Praktik-praktik pengajaran masih banyak yang dominasi oleh guru dan bahkan guru sepertinya memiliki otoritas untuk memaksa siswa memenuhi semua yang inginkannya, dengan kurang bijak memerhatikan kebutuhan belajar siswanya. Konsep mengajar dan belajar yang ideal harus diimbangi pula dengan perubahan wordview guru yang sesuai dengan kecenderungan perubahan tersebut, karena implementasi konsep mengajar untuk mengubah perilaku dari tidak tahu, dan tidak mengerti menjadi mengerti, dan dari tidak bisa menjadi bisa, memberi ruang kepada guru untuk dominan (Rosyada, 2013, hlm. 109).

Guru sebagai pelaku perubahan tidak lain adalah pemimpin (leader) perubahan bagi diri sendiri dan bagi orang lain sehingga mereka secara bersama-sama mampu membangun sebuah tatanan yang baru sesuai dengan cita-cita dan harapan mereka. Guru merupakan pemimpin (leader) dan perilaku perubahan pendidikan karena tanpa keterlibatan guru setiap usaha untuk memperbarui dunia pendidikan akan gagal. Dalam setiap pembaharuan di Sekolah, inisiatif perubahan yang tidak menyentuh kehidupan guru tidak akan mengubah banyak hal. Guru adalah garda terdepan dan pelaku perubahan dalam dunia pendidikan. Pemimpin heroik adalah mereka yang mampu menyelamatkan seluruh lembaga dan anggota-anggota dari jurang kehancuran. Mereka percaya bahwa individu itu dapat menjadi pemimpin besar karena ia terlahir untuk itu. Setiap orang terlahir dengan potensi menjadi pemimpin. Individu terlahir untuk menjadi pelaku perubahan dalam hidupnya dan membangun bagi masyarakatnya. Lebih dari itu, guru dapat berperan lebih aktif dalam menghadirkan tatanan baru masyarakat yang lebih adil dan manusiawi melalui kinerja pendidikan mereka (Albertus, 2015, hlm. 118-119).

Adanya keragaman perilaku siswa itu menimbulkan masalah bagi guru dan membingungkan. Untuk mengatasi masalah tersebut guru akan mengumpulkan berbagai informasi dari teman-teman dan masyarakat. Cara itu guru dapat mengelompokkan siswa dengan cara yang lebih bermakna, seperti: (1) melihat fakta secara tersendiri dalam hubungannya dengan prinsip umum adalah inti memahami yang digambarkan oleh batasan istilah diatas, (2) memahami penggunaan fakta, (3) mengerti sebagai kata benda. Agar tujuan mengajar dapat dicapai dengan sebaik-baiknya, maka perilaku dan mengarah pada penerapan prinsip-prinsip dan pendekatan-pendekatan pengajaran yang lebih modern. 
Pengajaran yang bermakna dalam arti memberi kemungkinan kepada siswa untuk berkembang dan untuk belajar lebih lanjut sekiranya merupakan salah satu prinsip utama dalam mengajar terutama mengajar mata pelajaran IPS/Sejarah (Wahab, 2009, hlm. 20-21).

Peranan strategi pengajaran lebih penting apabila guru mengajar siswa berbeda dari segi kemampuan, pencapaian, kecenderungan, serta minat. Hal tersebut karena guru harus memikirkan strategi pengajaran yang mampu memenuhi keperluan semua siswa. Di sini, guru tidak saja harus menguasai berbagai kaidah mengajar, tetapi yang lebih penting adalah mengintegrasikan serta menyusun kaidah-kaidah itu untuk membentuk strategi pengajaran yang paling berkesan dalam pengajarannya. Salah satu sasaran pembelajaran adalah membangun gagasan sainstifik setelah siswa berinteraksi dengan lingkungan, peristiwa, dan informasi dari sekitarnya. Pada dasarnya, semua siswa memiliki gagasan atau pengetahuan awal yang sudah terbangun dalam wujud skemata. Dari pengetahuan awal dan pengalaman yang ada, siswa menggunakan informasi yang berasal dari lingkungannya dalam rangka mengontruksi interpretasi pribadi seta makna-maknanya. Makna dibangun ketika guru memberikan permasalahan yang relevan dengan pengetahuan dan pengalaman yang sudah ada sebelumnya, memberi kesempatan kepada siswa menemukan dan menerapkan idenya sendiri (Hamdani, 2011, hlm. 23).

Pembelajaran yang berbasis atau bertumpu pada belajar aktif diarahkan agar proses pembelajaran menjadi lebih efektif. Pandangan bahwa mengajar adalah sebagai seni dan ilmu dan guru atau pengajar sekaligus harus menjadi guru yang efektif mempunyai konsekuensi yang cukup berat. Berbagai kompetensi- kompetensi dan aspek-aspek psikologi yang harus dikuasai dan dimiliki seorang guru yang efektif. Untuk dapat melaksanakan pembejaran yang mendidik dan dialogis sebagai salah satu kemampuan dalam kompetensi pedagogis, seorang guru harus mampu memilih dengan tepat metode atau teknik mengajar. Pada sisi lain Cole dan Chan, mengemukakan sebuah model mengenai prinsip-prinsip mengajar yang efektif yang telah teruji untuk berbagai bidang studi dengan ukuran keberhasilan tingginya prestasi belajar peserta didik apabila guru menerapkan model tersebut (Joyoatmojo, 2011, hlm. 58).

\section{Guru Sejarah Profesional Abad 21}

Pentingnya guru profesional dalam menyukseskan implementasi kurikulum 2013, dapat ditelusuri dalam setiap kegiatan pembelajaran, terutama yang dilaksanakan secara formal. Guru merupakan faktor penentu, karena yang terjadi di kelas adalah apa yang ada di dalam benaknya, sehingga banyak asumsi yang mengatakan bahwa di dalam kelas, guru adalah kurikulum. Dalam implementasi kurikulum 2013 guru tetap memegang peranan penting, baik dalam perencanaan, pelaksanaan maupun evaluasi, ini merupakan perencanaan, pelaksanaan, dan pengembangan kurikulum dikelasnya. Guru dalam melaksanakan tugasnya harus selalu bersikap terbuka, dan kritis untuk mengaktualisasi penguasaan isi bidang studi, pemahaman karakteristik peserta didik, dan melaksanakan pembelajaran yang mendidik (Mulyasa, 2015, hlm. 5-6).
Pandangan pedagogis dari ilmuwan pendidikan di awal paruh kedua abad ke-20 sudah berkembang menuju model pendidikan yang berpusat pada siswa, hanya saja keterlibatan dan peran guru dalam proses pengajaran masih sangat besar. Pandangan ini didasarkan oleh sebuah paradigma bahwa tingkat keberhasilan mengajar bukan pada seberapa banyak ilmu yang disampaikan guru kepada siswa, tetapi seberapa besar guru memberi peluang pada siswa untuk belajar dan memperoleh segala sesuatu yang ingin diketahuinya, guru hanya memfasilitasi para siswanya untuk meningkatkan keterampilan dan pengetahuannya. Kemudian, untuk menjadi bangsa yang tangguh, kuat, dan memiliki kemampuan kompetitif, pendidikan harus mampu melahirkan sumber daya manusia yang tidak saja memiliki kecerdasan majemuk tetapi juga memiliki kemampuan berpikir kritis dan berpikir kreatif (Rosyada, 2013, hlm. 101).

Ilmu pendidikan berkembang dengan pesat. Kemajuan teknologi digital berdampak besar terhadap segala bidang, termasuk pendidikan. Pemanfaatan teknologi digital dan internet untuk proses pembelajaran berdampak terhadap pola belajar seseorang. Teknologi muncul karena manusia itu berpikir dan bekerja keras untuk memfasilitasi kehidupan setiap anggota masyarakat menjadi baik. Mau tidak mau, jika seorang peserta didik sedang mengikuti e-learning, maka ia dihadapkan kepada satu monitor dan satu perangkat komputer, apapun jenisnya. Interaksi sosial atau komunikasi secara fisik sebaiknya tetap harus disediakan seperti dalam proses hybrid learning. Tentu saja upaya yang bersifat konstruktivistik harus tetap dipenuhi oleh program e-learning ini. Teknologi menjadi bukti kebudayaan dan peradaban manusia yang memiliki pemikiran modern dan bermanfaat bagi sesama (Prawiradilaga, 2012, hlm. 19).

Guru sejarah memiliki peranan penting dalam keseluruhan proses pembelajaran sejarah. Setiap guru sejarah harus memperluas pengetahuan historisnya dengan menguasai beberapa pengetahuan dasar dari ilmu-ilmu yang berkaitan seperti bahasa modern, sejarah filsafat, sejarah sastra, dan geografi, sebab pengetahuan seperti ini akan memperkuat pembelajaran sejarah. Guru semacam itu menggunakan media pembelajaran yang bervariasi untuk menciptakan kembali masa lampau dan orang-orang yang berada di dalamnya, sebagai bantuan bagi siswa agar dapat merasakan semangat dari setiap masa. Kemampuan untuk menguasai bentukbentuk tes objekttif, tes dengan jawaban singkat, dan skala rating yang objektif dalam memberi nilai sangat penting bagi guru seejarah (Kochhar, 2008, hlm. 395-396).

Perkembangan ilmu pengetahuan, teknologi, dan arus globalisasi telah membawa perubahan di hampir semua aspek kehidupan manusia. Dalam rangka menghadapi berbagai permasalahan yang ditimbulkan oleh proses globalisasi pada satu pihak dan proses demokratisasi pada pihak lain, sangat diperlukan sumber daya manusia yang lebih berkualitas melalui pembaharuan sistem pendidikan dan menyempurnakan kurikulum, termasuk kurikulum sejarah yang berbasis kompetensi, demokrasi, dan berwawasan lokal, namun tetap memperhatikan standar nasional. Berdasarkan pemahaman bahwa sejarah merupakan ilmu yang mempelajari 
proses perubahan dan keberlanjutan dalam dimensi waktu, maka pengajaran sejarah di Sekolah perlu dilaksanakan untuk membangun pemahaman keilmuan berperspektif waktu, memori bersama, dan kesadaran terhadap nilai inti bangsa (Agung \& Wahyuni, 2013, hlm. 51-52)

Pembelajaran sejarah sebagai sub-sistem dari sistem kegiatan pendidikan, merupakan sarana yang efektif untuk meningkatkan integritas dan kepribadian bangsa melalui proses belajar mengajar. Keberhasilan ini akan ditopang oleh berbagai komponen, termasuk kemampuan dalam menerapkan metode pembelajaran yang efektif dan efesien. Sistem kegiatan pendidikan dan pembelajaran adalah sistem kemasyarakatan yang kompleks, diletakkan sebagai suatu usaha bersama untuk memenuhi kebutuhan pendidikan dalam rangka untuk membangun dan mengembangkan diri. Sistem umpan balik yang efektif bermaksud menjembatani gap yang ada antara pendidik dan peserta didik dalam proses pembelajaran. Pendidik selayaknya meluangkan wakktu diakhir sesi pembelajaran untuk kesimpualan umum dan mengadakan dialog dengan peserta didik (Aman, 2011, hlm. 66-67).

Motivasi belajar peserta didik setiap saat dapat berubah. Hal itu dipengaruhi oleh kondisi internal (pribadi) dan eksternal (lingkungan) belajarnya. Mahasiswa yang memiliki motivasi belajar yang tinggi tampak pada gairah belajarnya, antara lain pada sikap aktif di kelas serta rajin dan disiplin. Sebaliknya beberapa tanda yang tampak dari mahasiswa yang tidak motivasi belajarnya rendah: (1) sering terlambat masuk kelas, (2) malas belajar dan mengerjakan tugas-tugas yang diberikan oleh pengajar, (3) pasif pada saat belajar, dan (4) penampilannya tidak rapi. Motivasi belajar peserta didik setiap saat dapat berubah. Karena itu diperlukan penyadaran diri, baik yang bersumber dari dalam (internal) maupun dari luar (eksternal). Terhadap sikap dan motivasi belajar yang tinggi, pengajar diharapkan terus memupuk suasana itu dengan baik lewat interaksi pembelajaran yang aktif. Dalam kaitan itu, peran pengajar sangat penting untuk membangkitkan semangat belajar peserta didik (Hamid, 2014, hlm. 52-53).

\section{Peran Guru Sejarah Abad 21 dalam Menghadapi Tantangan Arus Globalisasi}

Guru di era globalisasi adalah guru dengan profesionalitas tinggi yang mempunyai tugas yang tidak akan semakin ringan, maka harus berkualitas. Ciri sumber daya manusia adalah memiliki kemampuan dalam menguasai keahlian dalam suatu bidang yang berkaitan dengan iptek, mampu bekerja secara profesional dengan orientasi mutu dan keunggulan, dan dapat menghasilkan karya-karya unggul yang mampu bersaing secara global sebagai hasil dari keahlian dan profesionalitasnya. Globalisasi dengan dominasi teknologi dan informasi yang sangat kuat dapat bagaikan gelombang yang akan menerjang "benda-benda" di depannya tanpa kompromi. Arus globalisasi siap mendobrak semua aspek kehidupan termasuk pendidikan. Dalam upaya meningkatkan kualitas pengajaran, guru dengan profesionalitasnya harus bisa mengembangkan tiga intelegensi dasar peserta didik, yaitu intelektual, emosional, dan moral. Tiga unsur tersebut harus ditanamkan pada diri peserta didik, sekuat-kuatnya agar terpatri di dalam dirinya (Syukur, 2012, hlm. 20-21).

Era global memberikan perubahan besar pada tatanan dunia secara menyeluruh dan perubahan itu dihadapi bersama sebagai suatu perubahan yang wajar. Sebab mau tidak mau, siap tidak siap perubahan itu akan terjadi. Era ini ditandai dengan proses kehidupan mendunia, kemajuan ilmu pengetahuan dan teknologi, terutama dalam bidang transformasi dan komunikasi serta terjadinya lintas budaya. Perubahan yang dibawa oleh globalisasi ini, mau atau tidak mau juga dialami oleh dunia pendidikan dengan tantangan guru sebagai praktisinya. Ada beberapa tantangan yang harus dihadapi guru di era global dengan harus mengedepankan profesionalismenya, seperti perkembangan ilmu pengetahuan dan teknologi yang begitu cepat dan mendasar. Krisis moral yang melanda Indonesia, krisis sosial dan krisis identitas sebagai bangsa dan negara Indonesia. Semua itu jelas menuntut calon guru dan pendidik yang bermutu (Oviyanti, 2013, hlm. 281-282).

Di abad 21, pekerjaan guru merupakan pekerjaan yang kompleks dan tidak mudah seiring dengan perubahan besar dan cepat pada lingkungan Sekolah yang didorong oleh kemajuan ilmu dan teknologi, perubahan demograsi, globalisasi dan lingkungan. Guru profesional tidak lagi sekedar guru yang mampu mengajar dengan baik, melainkan guru yang mampu menjadi pembelajar dan agen perubahan Sekolah, dan juga mampu menjalin dan mengembangkan hubungan untuk peningkatan mutu pembelajaran di Sekolahnya. Untuk itu, guru membutuhkan pengembangan profesional yang efektif, yaitu bimbingan. Pelaksanaan pembimbingan yang efektif perlu mempertimbangkan hal-hal yang mempengaruhi mutu hubungan pembimbingan, seperti struktur organisasi pembimbingan, kontrak kerja, mutu pembimbing, aktivitas dalam sesi-sesi awal sampai akhir pembimbingan. Untuk menguatkan fungsi dan manfaatnya, pembimbingan perlu diprogramkan. Hal ini membutuhkan perubahan struktur, budaya dan juga dukungan kepemimpinan dari Sekolah dan juga institusi terkait (Andriani, 2010, hlm. 14).

Menampilkan ilmu-ilmu sosial dengan cara itu dapat memberi peluang bagi para pengembang kurikulum IPS/ Sejarah untuk mengembangkannya berdasarkan pemahaman minimum yang dapat disusun secara baik dalam bentuk paket untuk setiap tingkatan yang berbeda. Salah satu cara untuk membantu siswa sampai pada pengertian mereka sendiri adalah dengan meminta siswa untuk mengganti konsep dengan uraian kata (descriptive words). Jadi generalisasi yang berbunyi "Pembagian kerja dapat meningkatkan efesiensi para pekerja, sehingga mereka dapat lebih banyak memproduksi barang dalam waktu yang sama atau waktu yang lebih kurang" (Wahab, 2009, hlm. 132).

Perencanaan dan pengembangan kurikulum harus didasarkan pada ide-ide umum tentang kurikulum yang muncul berkat interaksi antara teori dan praktik. Pembelajaran terkait dengan tujuan dan rencana kurikulum, yang difokuskan pada persoalan metodologi, seperti teknik mengajar, kegiatan implementasi sumber, dan alat pengukuran yang digunakan dalam situasi belajar mengajar yang khusus. Pengembangan

HISTORIA: Jurnal Pendidik dan Peneliti Sejarah, p-issn:2620-4789 | e-issn:2615-7993 
kurikulum memberi pedoman pada desain instruksional, dan desain instruksional merujuk kegiatan spesifik yang terpusat pada metode belajar mengajar. Para pendidik (educators) mempunyai wewenang melakukan studi dan memberikan komentar terhadap kurikulum luar Sekolah sebagai bagian dari tanggung jawab profesional secara keseluruhan. Hal ini diakibatkan para siswa (pemuda) mempelajari banyak hal dari berbagai pengalaman luar Sekolah. Oleh karena itu, para pendidik harus bersifat aktif berkenaan dengan hakikat belajar tersebut (Hamalik, 2013, hlm. 24-27).

Seorang guru harus menggunakan metode yang dapat membuat suasana kelas menjadi sebuah tempat dengan standar yang tinggi dan semua orang di dalamnya dapat bekerja keras serta bersama-sama dengan siswa bekerja sama sebagai tim untuk mencari solusi masalah-masalah penting dan meraih hasil yang signifikan. Guru sejarah harus memiliki pengetahuan yang baik dalam penggunaan dan pengoperasian alat-alat bantu mekanis jenis yang baru, seperti epidiaskop, proyektor filmstrip, dan proyektor film. Guru sejarah harus diberi kesempatan untuk mengikuti konferensi sejarah di tingkat lokal, regional, dan nasional, serta mengambil bagian dalam diskusi mengenai buku-buku pelajaran dan metode audiovisual yang digunakan oleh negaranya sendiri dan negara-negara lain. Guru sejarah harus memiliki pengetahuan tentang studi-studi yang dilakukan oleh UNESCO mengenai berbagai aspek bangsa. Ia harus mempelajari organisasiorganisasi internasional dalam hubungannya dengan evolusi historisnya. Guru sejarah harus menyelidiki asal mula perbuatan manusia di masa lampau dengan semangat seorang penjelajah (Kochhar, 2008, hlm. 395-397).

Sedangkan dalam menyusun kurikulum Sejarah yang sesuai dengan perubahan zaman, maka legalitas pendidikan sejarah dalam kurikulum pendidikan nasional harus menekankan aspek-aspek penting materi pelajaran Sejarah. Di mana kurikulum harus menekankan pentingnya pengajaran Sejarah sebagai sarana pendidikan bangsa, sebagai sarana pembangunan bangsa secara mendasar, menanamkan national consciousness dan Indonesiahood sebagai sarana menanamkan nasionalisme, perlunya pengakuan pemerintah akan pentingnya pendidikan Sejarah sebagai sarana untuk membentuk jati diri dan integrasi bangsa serta rumusan Sejarah sebagai mata pelajaran yang menanamkan pengetahuan dan nilai-nilai proses perubahan dan perkembangan masyarakat Indonesia dan dunia dari masa lampau sampai masa kini (Aman, 2011, hlm. 71).

Mata pelajaran Sejarah di Sekolah memiliki posisi yang cukup penting bagi pengembangan identitas bangsa. Namun, perlu disadari juga bahwa arti penting pelajaran Sejarah tidak dapat dengan sendirinya berkembang tanpa adanya usaha untuk mewujudkannya. Khusus dalam pengajaran Sejarah, seorang guru Sejarah dituntut untuk dapat memenuhi kemampuan sebagai berikut: 1) Seorang guru Sejarah seharusnya memiliki kualitas prima dalam masalah kemanusiaan. 2) Orang-orang yang memiliki pengetahuan luas tentang kebudayaan. 3) Guru Sejarah juga seharusnya merupakan pengabdi perubahan. Berpikir hostoris adalah berpikir bahwa segala sesuatu akan bergerak atau berubah, cepat dan lambat. 4) Guru Sejarah seharusnya adalah pengabdi kebenaran. Dalam hal ini, kita menyadari bahwa suatu kenyataan atau kebenaran dalam ilmu sosial memiliki banyak sisi yang merupakan bagian integral dari kenyataan tersebut (Agung \& Wahyuni, 2013, hlm. 8992).

Berbagai pengalaman dan pelajaran dari Sejarah pengasingan tokoh-tokoh pergerakan nasional di Bovel Digoel sangat penting dipahami oleh pendidik dan peserta didik. Ada dua upaya yang dapat dilakukan untuk mentransfer pengetahuan kesejarahan. Pertama, pengembangan kegiatan wisata Sejarah. Peserta didik diajak oleh gurunya untuk melihat dan mengenal dari dekat obyek-obyek Sejarah. Kedua, pembuatan rekaman (diorama) Sejarah yang diangkat dari hasil kunjungan lapangan dan bacaan terhadap sumbersumber Sejarah. Kedua cara tersebut diharapkan dapat membangkitkan kesadaran Sejarah yang kuat untuk menerima realitas ke Indonesiaan, yang telah dibayar mahal oleh kaum interniran.

Depot pengetahuan masa lalu ini merupakan kekayaan berharga yang dapat dimanfaatkan sebagai pondasi pembentukan karakter generasi muda dan sekaligus bahan pembelajaran berbasis karakter. Pembukaan dan pemanfaatan kamp Boven Digul mengisahkan beragam pelajaran berharga yang harus diketahui oleh anak bangsa. Bahwa negara yang kita tempat sekarang tidak terbentuk dengan sendirinya. Para pejuang telah membayar mahal mimpi-mimpi mereka, untuk menjadi negara merdeka dan berdaulat, yang kita nikmati sekarang. Sejarah menyajikan banyak pelajaran berharga yang dapat dijadikan sumber teladan dalam pembentukan karakter anak bangsa (Hamid, 2014, hlm. 179).

Kesadaran Sejarah tidak lain dari pada kondisi kejiwaan yang menunjukkan tingkat penghayatan pada makna dan hakikat Sejarah bagi masa kini dan bagi masa yang akan datang. Dalam hal ini, wacana tentang masa lampau bukan hanya sekedar akan melahirkan pengetahuan Sejarah, pada gilirannya juga akan menuntut untuk tidak dipisahkan dari dorongan masyarakat terhadap lahirnya peristiwa Sejarah, dimana Sejarah selalu dilahirkan oleh kontemplasi tentang 'nasib kemanusiaan'. Persoalan yang berkaitan dengan ketepatan faktual (historical truth atau historical certainty) adalah dengan menerapkan ilmu Sejarah kritis, sehingga akan memilahkan persoalan antara yang bersifat akademis dan yang bersifat politis. Kualitas pembelajaran Sejarah terdiri terdiri dari tujuh komponen, yaitu kinerja guru Sejarah, materi pelajaran Sejarah, metode pembelajaran, sarana pembelajaran Sejarah, iklim kelas, sikap siswa, dan motivasi belajar Sejarah. Sedangkan hasil pembelajaran Sejarah terdiri dari tiga komponen, yaitu kecakapan akademik, kesadaran Sejarah, dan sikap nasionalisme (Aman, 2011, hlm. 142-144).

Dunia dan masyarakat menawarkan nilai-nilai baru yang bisa selaras dengan cita-cita pendidikan, namun dapat juga bertentangan dengan logika yang berlaku dalam dunia pendidikan. Guru dapat menjadi pendidik karakter jika memiliki sikap terbuka dan kritis serta kemauan untuk menemukan dan menegaskan kembali nilai-nilai yang diyakininya selama ini. Dinamika masyarakat yang senantiasa berubah menbuat fungsi, peran, dan status guru senantiasa 
ada dalam proses perubahan dan pencarian diri terus menerus. Dimana terjebak antara masa depan dan masa lalu, guru seharusnya menghayati makna pekerjaannya di masa kini dengan tetap merawat visi dan inspirasi yang menjadi roh dan jiwa bagi kinerjanya sekarang tanpa terjebak dalam logika kecepatan, efesiensi, dan efektivitas yang menjerumuskan dalam sindrom kekinian. Visi dan inspirasi guru ini harus ditelaah, direfleksikan, dan dikritisi secara terus menerus agar nilai-nilai yang diyakini benar-benar selaras dengan apa yang menjadi hakikat dasar sebuah pendidikan (Albertus, 2015, hlm. 142-143).

\section{SIMPULAN}

Guru merupakan tonggak utama dalam pendidikan di dunia. Perannya sebagai pendidik tidak lepas dari pengembangan ilmu pengetahuan yang dimiliki seorang guru. Guru profesional adalah guru yang menjadi sumber inspirasi dan pematik gairah belajar bagi anak didiknya, karena guru meyakini kepentingan ilmunya ini demi masa depan anakanaknya. Guru Sejarah yang merupakan guru yang harus terus belajar untuk mengimbangi antara ilmunya dimasa lalu, masa sekarang dan masa yang akan datang. Seorang guru Sejarah harus mampu melihat karakter anak didiknya dan menghargai setiap perbedaan yang menjadi latar belakang siswanya. Pembentuk mental dan karakter siswa, tidak akan lepas dari persoalan penanaman nilai-nilai, transfer of values. Oleh karena itu, guru tidak sekedar pengajar, tetapi benarbenar sebagai pendidik yang akan memindahkan nilai-nilai itu kepada anak didiknya. Menjadi guru Sejarah yang ramah, harmonis dan cerdas berwawasan global sangat dibutuhkan bagi dunia pendidikan saat ini.

Di abad ke-21 dimana semua yang terjadi dunia ini terpengaruh oleh globalisasi yang juga menghampiri dunia pendidikan seharusnya guru juga terus berjuang untuk tetap komitmen mendidik anak didiknya dan mengajarkan nilai karakter bangsa. Inovasi pembelajaran sangat diperlukan dalam dunia pendidikan, maka dari itu munculnya globalisasi harus dimanfaatkan dampak positifnya dan menghindari dampak buruknya bagi pendidikan. Memberikan motivasi kepada siswa, di era globalisasi saat itu semangat belajar siswa harus bertambah tinggi dan lebih baik sehingga memperoleh prestasi belajar yang lebih tinggi. Abad-21 globalisasi boleh muncul dan berkembang, namun prestasi dan nilai karakter bangsa tetap terjaga dengan baik. Dalam pembelajaran Sejarah, seorang guru perlu menerapkan inovasi pembelajaran yang dirancang untuk membantu siswa agar mudah memahami fakta, peristiwa, konsep, dan generalisasi melalui pengalaman belajar empiris. Pembelajaran Sejarah perlu menggunakan berbagai media yang mempunyai potensi untuk menambah wawasan dan konteks belajar serta meningkatkan hasil belajar. Sejarah

\section{REFERENSI}

Albertus, Doni Koesoema. (2015). Pendidikan Karakter di Zaman Keblinger. Jakarta: Gresindo.

Agung, Leo \& Wahyuni, Sri. (2013). Perencanaan Pembelajaran Sejarah. Yogyakarta: Ombak.
Aman. 2011. Model Evaluasi Pembelajaran Sejarah. Yogyakarta: Ombak.

Andriani, Dwi Esti. (2010). Pengembangan Profesionalitas Guru Abad 21 Melalui Program Pembimbingan yang Efektif. Jurnal Manajemen Pendidikan, Volume 6. No. 2, Oktober 2010. Jurnal Manajemen Pendidikan FIP UNY Yogyakarta.

Daryanto \& Rahardjo, Muljo. (2012). Model Pembelajaran Inovatif. Yogyakarta: Gava Media.

Hamalik, Oemar. (2013). Dasar-Dasar Pengembangan Kurikulum. Bandung: Rosda.

Hamdani. (2011). Strategi Belajar Mengajar. Bandung: Pustaka Setia.

Hamid, Abd. Rahman. (2014). Pembelajaran Sejarah. Yogyakarta: Ombak.

Joyoatmojo, Soetarno. (20110. Pembelajaran Efektif Pembelajaran yang Membelajarkan. Surakarta: UNS Press.

Kochhar, S.K. (2008). Pembelajaran Sejarah: Teaching of History. Jakarta: Grasindo.

Mulyasa, E. 2015. Guru Dalam Implementasi Kurikulum 2013. Bandung: Remaja Rosdakarya.

Oviyanti, Fitri. (2013). Tantangan Perkembangan Pendidikan Keguruan di Era Globalisasi. Jurnal Pendidikan Islam, Volume 7, No. 2, Oktober 2013. Jurnal Pendidikan Agama Islam IAIN Raden Fatah Palembang.

Prawiradilaga, Dewi Salma. (2012). Wawasan Teknologi Pendidikan. Jakarta: Prenadamedia Group.

Rosyada, Dede. (2013). Paradigma Pendidikan Demogratis: Sebuah Model Pelibatan Masyarakat dalam Penyelenggaraan Pendidikan. Jakarta: Prenadamedia Group.

Sanjaya, Wina. (2016). Strategi Pembelajaran Berorientasi Standar Proses Pendidikan. Jakarta: Prenadamedia Group.

Satori, Djama’an \& Komariah, Aan. 2010. Metode Penelitian Kualitatif. Bandung: Alfabeta.

Siagian, Sondang P. (2012). Teori Motivasi dan Aplikasinya. Jakarta: Rineka Cipta.

Sugiyono. (2012). Metode Penelitian Kuantitatif, Kualitatif Dan $R$ \& D. Bandung: Alfabeta.

Sutopo. (2006). Metodologi Penelitian Kualitatif. Surakarta: UNS Press.

Syukur, Sf Mahlaih. (2012). Profesionalisme Guru dan Globalisasi (Karakter Guru Profesional di Era Global). Proceeding Seminar Nasional Tahun 2012. ISBN: 978602-18235-0-7. Pascasarjana Universitas Wahid Hasyim Semarang.

Triyanto. (2007). Model-Model Pembelajaran Inovatif Berorientasi Konstruktivistik. Jakarta: Prestasi Pustaka Publisher.

Wahab, Abdul Aziz. (2007). Metode dan Model-Model Mengajar Ilmu Pengetahuan Sosial (IPS). Bandung: Alfabeta.

HISTORIA: Jurnal Pendidik dan Peneliti Sejarah, p-issn:2620-4789 | e-issn:2615-7993 